ECONOMICA

Journal of Economic and Economic Education Vol.1 No.1 (133-147)

\title{
PENGARUH PDB RIIL DAN VARIABEL FISKAL TERHADAP PENANAMAN MODAL ASING LANGSUNG DI INDONESIA
}

\author{
Yosi Eka Putri \\ Dosen Program Studi Pendidikan Ekonomi STKIP- PGRI Sumbar \\ Jl. Gunung Pangilun No.1, Padang Sumatera Barat \\ Email: yossy_ekaputri@yahoo.com
}

Submitted: 2012.09.18 Reviewed: 2012.09.29 Accepted: 2012.10.18

http://dx.doi.org/10.22202/economica.2012.v1.i1.113

\begin{abstract}
This study aims to determine the influence of Real GDP and fiscal variables for foreign direct investment in Indonesia in period 1980 to 2006, and also to determine the level of sensitivity (elasticity) of foreign direct investment to GDP Real and fiscal variables in Indonesia in 1980 to 2006. The data used in this study is time series data or annual data for 27 years secondary. Data obtained from Statistics Economics and Finance Indonesia (SEKI) BI. The research method used a model with a Multiple Linear Regression analysis: analysis of correlation $(R)$, the analysis of the coefficient of determination $\left(R^{2}\right)$, the elasticity analysis, and test the stability of the model, while the tests performed were $F$ test, $t$ test, and test autocorrelation with Durbin Watson and multicollinearity test using Eviews program. From the results of this study showed that $96.16 \%$ of foreign direct investment in Indonesia is influenced by real GDP, income tax, property tax, sales tax, economic development spending, government spending on transport and communications, government spending on education, as well as the economic crisis while the rest of $3.84 \%$ influenced by other factors outside the model. Effect of Real GDP, PBB, government spending on transport and communications and in partial dummy variable is not significant while the Income Tax, sales tax, government spending for education and development are significant on direct foreign investment in Indonesia from 1980 to 2006.
\end{abstract}

\begin{abstract}
Abstrak
Penelitian ini bertujuan untuk mengetahui pengaruh GDP riil dan variabel fiskal untuk investasi langsung asing di Indonesia pada periode 1980-2006, dan juga untuk menentukan tingkat sensitivitas (elastisitas) dari investasi asing langsung ke PDB riil dan variabel fiskal di Indonesia pada tahun 1980 untuk tahun 2006. Data yang digunakan dalam penelitian ini adalah time series data atau data tahunan selama 27 tahun sekunder. Data yang diperoleh dari Statistik Ekonomi dan Keuangan Indonesia (SEKI) BI. Metode penelitian menggunakan model dengan analisis regresi linier Beberapa: analisis korelasi ( $R$ ), analisis koefisien determinasi (R2), analisis elastisitas, dan menguji stabilitas model, sedangkan tes yang dilakukan adalah uji $F$, uji $t$, dan uji autokorelasi dengan Durbin Watson dan uji multikolinieritas menggunakan program Eviews. Dari hasil penelitian ini menunjukkan bahwa 96,16\% dari investasi langsung asing di Indonesia dipengaruhi oleh GDP riil, pajak penghasilan, pajak properti, pajak penjualan, belanja pembangunan ekonomi, pengeluaran pemerintah pada transportasi dan komunikasi, pengeluaran pemerintah untuk pendidikan, serta krisis ekonomi sedangkan sisanya sebesar 3,84\% dipengaruhi oleh faktor lain di luar model. Pengaruh Real GDP, $P B B$, pengeluaran pemerintah pada transportasi dan komunikasi dan variabel dummy parsial tidak signifikan sedangkan Pajak Penghasilan, pajak penjualan, pengeluaran pemerintah untuk pendidikan dan pembangunan yang signifikan terhadap investasi asing langsung di Indonesia 1980-2006.
\end{abstract}

Keywords : Foreign Direct Investment, Real GDP, Fiscal Variable, Government Spending, Tax

(C2012 Prodi Pendidikan Ekonomi STKIP PGRI, Padang 


\section{PENDAHULUAN}

Kesejahteraan masyarakat dan perkembangan perekonomian yang baik merupakan salah satu tujuan yang ingin dicapai setiap negara. Indonesia sebagai negara berkembang, sudah pasti berkeinginan untuk meningkatkan pertumbuhan ekonominya, untuk mencapai pertumbuhan ekonomi yang dikehendaki. Maka diperlukan sejumlah investasi yang dibiayai oleh tabungan nasional. Tetapi di negara berkembang seperti Indonesia tidak mempunyai dana yang cukup untuk membiayai pembangunan ekonomi karena terbatasnya akumulasi berupa kapital tabungan nasional serta rendahnya produktivitas dan tingginya konsumsi, sehingga diperlukan sumber dana lain yaitu investasi asing atau penanaman modal asing langsung.

Penanaman modal asing langsung merupakan alternatif sumber dana pembangunan yang relatif lebih aman dibandingkan dengan pinjaman luar negeri. Pinjaman luar negeri baik dalam bentuk pinjaman bank maupun pinjaman resmi adalah bentuk-bentuk instrumen dimana si penerima pinjaman harus membayar jumlah pokok ditambah bunga apapun kondisi ekonominya. Sedangkan penanaman modal asing langsung adalah bentuk instrumen modal imbalan yang harus diberikan tidak dalam jumlah yang pasti, melainkan tergantung pada kondisi ekonomi si penerima. Jadi instrumen modal jauh lebih baik daripada instrumen hutang bagi negara berkembang. (Krugman, 2000)

Penanaman modal asing (PMA) menjadi alternatif untuk memenuhi kebutuhan modal pembangunan. Di Indonesia, PMA diatur dalam Undang-undang Penanaman Modal Asing (UUPMA) yang merupakan landasan hukum mengalirnya PMA ke Indonesia. Pemerintah Indonesia berusaha mendorong iklim usaha sehingga mampu menarik minat usaha khususnya bagi sektor swasta asing, sehingga lahirlah UndangUndang No. 1/Tahun 1967 tentang Penanaman Modal Asing (PMA). Seiring berjalannya waktu undang-undang tersebut dilengkapi dan disempurnakan pada tahun 1970 yaitu, Undang-Undang No. 1/ Tahun 1967 tentang PMA disempurnakan oleh Undang-Undang No. 11 / Tahun 1970.(BKPM, 1970)

Perkembangan penanaman modal asing langsung di Indonesia sendiri secara lengkap telah diteliti oleh Foreign Investment Advisory Service (FIAS) dari periode ke periode. Pada periode tahun 1987 untuk pertama kalinya perusahaan milik asing diperbolehkan mengekspor hasil produknya untuk meningkatkan aktivitas sektor perdagangan. Pada tahun 1989 sektor yang tertutup bagi penanaman modal asing dikurangi dari 64 sektor menjadi 35 sektor, setelah terjadi boom investasi pada tahun 1989-1991.(World Investment Report, 1999)

Kehadiran penanaman modal asing di negara kita bukan merupakan sesuatu yang baru bagi negara dan masyarakat Indonesia. FDI sempat menjadi primadona dalam mitra pembangunan saat negara kita melaju pada tingkat percepatan pertumbuhan ekonomi yang tinggi di atas $7 \%$ per tahunnya, saat sebelum krisis perekonomian terjadi. Bersama-sama dengan investasi masyarakat dan PMDN, penanaman modal secara keseluruhan telah tumbuh rata-rata sekitar $10, \%$ per tahun pada periode 1991-1996 dengan kontribusi hampir mencapai $30 \%$ terhadap Produk Domestik Bruto. Kinerja penanaman modal yang kurang baik sejak 1996 menyebabkan lambannya proses pemulihan ekonomi negara kita beberapa tahun setelah krisis. (Laporan BI, 2000)

Setelah Rezim orde baru tumbang pada tahun 1998, perekonomian Indonesia mengalami penurunan yang sangat signifikan, hal ini disebabkan terjadi krisis moneter di negara-negara Asia yang kemudian berimbas menjadi krisis ekonomi yang sangat parah. Krisis mata uang di Indonesia terjadi sejak juli 1997, yang dipicu oleh efek penularan (contagion effect) dari krisis Thailand. Laju pertumbuhan ekonomi Indonesia menurun menjadi 4,7\% pada tahun 1997 dan kemudian merosot secara signifikan menjadi $-13,2 \%$ pada tahun 1998. (Biro Pusat Statistik, 2000). Hal ini telah menyebabkan terjadinya capital 
outflow dalam jumlah yang besar dan mendadak sehingga menimbulkan dampak yang sangat parah pada sektor perbankan dan usaha. Adanya capital outflow ini dapat menimbulkan suatu gangguan dalam perekonomian nasional.

Kehancuran perekonomian Indonesia telah membuka mata kita bahwa pertumbuhan ekonomi yang signifikan selama ini ternyata tidaklah dibarengi dengan pembangunan pondasi perekonomian yang kuat dan kokoh, sehingga pada saat krisis ekonomi menerpa negara kita perekonomian Indonesia langsung ambruk dengan adanya capital outflow yang sangat besar pada masa krisis. Dan sampai saat ini kita masih tertinggal dengan negaranegara lain yang juga mengalami krisis seperti Thailand dan Malaysia yang sudah mulai dapat keluar dari kondisi krisis ini.(Robiyana, 2003)

Perkembangan penanaman modal asing langsung yang masuk ke Indonesia memang cukup signifikan. Namun secara rata-rata bila dibandingkan dengan negara Malaysia, Thailand, Singapura, Korea, dan Cina, penanaman modal asing langsung ke Indonesia masih kalah bersaing. Ini membuktikan bahwa negara-negara tersebut lebih menarik bagi investor asing untuk menanamkan modalnya dibandingkan Indonesia sehingga harus diamati dan diawasi, jangan sampai arus penanaman modal asing langsung beralih ke negaranegara tersebut mengingat negara-negara tersebut mengalami peningkatan pertumbuhan ekonomi, menawarkan berbagai insentif dan stabilitas sosial politik yang lebih baik.(World Development Indicator, 2000)

Laporan Bank Dunia menyebutkan Indonesia merupakan negara yang mengalami penurunan penanaman modal asing yang paling tajam dibanding negara-negara berkembang lainnya. United Nations Conference on Trade and Development (UNCTAD) dalam laporannya mengenai investasi dunia pada tahun lalu menempatkan Indonesia pada urutan ke-135 dari 170 negara di dunia. (World Bank, 2007). Selain itu, negara ini juga dinilai sebagai wilayah yang kurang menguntungkan sebagai tempat untuk berbisnis dibanding negara-negara tetangganya seperti Filipina, Thailand dan Malaysia.

Motivasi dari kegiatan penanaman modal asing langsung ke luar negeri yaitu untuk mendapatkan return yang lebih besar (yang mungkin berasal dari pertumbuhan yang lebih tinggi di luar negeri, perlakuan pajak yang lebih menguntungkan, atau ketersediaan infrastruktur yang lebih baik) dan untuk mendiversivikasi resiko. Untuk menarik penanaman modal asing langsung, negara tuan rumah biasanya berkompetisi ketat untuk menawarkan insentif perdagangan untuk mengurangi biaya kapital bagi investor asing. Tetapi, di negara tuan rumah terkadang ada kekurangan transparansi dalam praktek insentif. Ini membuatnya sulit untuk menghitung dan membandingkan keuntungan, pertumbuhan ekspor, biaya, jumlah pengeluaran infrastruktur dan kerugian penerimaan pajak, dalam mengevaluasi keefektifan insentif perdagangan dalam kompetisi untuk mendatangkan penanaman modal asing langsung. Meskipun demikian, pembuat kebijakan percaya keuntungan dari usaha ini melebihi biayanya.(Aditiawan,2007 )

Salah satu kebijakan pemerintah yang sangat berpengaruh terhadap penanaman modal asing yaitu kebijakan fiskal. Kebijakan pemerintah ini merupakan langkah pemerintah untuk membuat perubahan dalam bidang perpajakan dan pengeluaran pemerintah dengan maksud untuk mempengaruhi pengeluaran agregat dalam perekonomian. Kebijakan fiskal dibuat untuk mengatasi masalah perekonomian yang tidak stabil dalam keseimbangan jangka panjang seperti depresiasi (dapat menyebabkan devaluasi) dan inflasi.

Pengeluaran pemerintah merupakan komponen utama sebagai penggerak roda perekonomian karena berguna untuk meningkatkan dan merangsang kegiatan ekonomi secara umum. Dimana ketika pemerintah menggelontorkan keuangannya untuk membuat fasilitas umum yang menunjang perekonomian, maka perbaikan ekonomi dapat dilaksanakan. Dan para 
investor tertarik untuk menanamkan modalnya ketika fasilitas perekonomian cukup memadai. Apabila pengeluaran pemerintah semakin tinggi, maka pengeluaran agregat dan selanjutnya tingkat kegiatan ekonomi akan bertambah tinggi. (Assahinur, 2003)

Adapun sumber pengeluaran pemerintah berasal dari penerimaan pemerintah melalui pajak. Pajak adalah suatu pungutan yang merupakan hak prerogatif pemerintah. Pajak merupakan sumber utama yang dapat digunakan dalam memacu penerimaan pemerintah. Melalui pajak pemerintah dapat mempengaruhi perekonomian, ketika pajak yang dibebankan pemerintah terlalu tinggi, dapat berpengaruh terhadap minat investor untuk menanamkan modalnya. Jadi jelaslah bahwa kebijakan fiskal berpengaruh terhadap penanaman modal asing di Indonesia. (BKPM, 2001)

Faktor-faktor yang mempengaruhi investasi asing yang mengalir ke Indonesia dapat kita lihat dari sudut pandang negara Indonesia itu sendiri sebagai negara yang membutuhkan investasi asing, atau juga dapat dilihat dari sudut pandang investor asing yang akan menanamkan modalnya di Indonesia, sehingga faktor tersebut akan mempengaruhi keputusan investor asing itu dalam menanamkan modalnya di Indonesia.

Beberapa faktor negara tuan rumah yang diduga memiliki pengaruh terhadap investasi asing terdiri dari tiga faktor utama. Pertama, kerangka kebijakan untuk penanaman modal asing langsung yang terdiri dari stabilitas sosial ekonomi dan politik, peraturan mengenai cara masuk dan operasi, perlakuan standar untuk penanaman modal asing langsung, kebijakan struktur pasar (merger dan akuisisi), perjanjian internasional penanaman modal asing langsung, kebijakan privatisasi, kebijakan perdagangan (hambatan tariff dan non-tariff) dan kebijakan pajak. Kedua adalah faktor dari perusahaan yang terbagi atas (i) faktor mencari pasar sehingga mencari ukuran pasar dan pendapatan perkapita, pertumbuhan pasar, akses ke pasar regional dan internasional, keinginan konsumen, dan struktur pasar; (ii) mencari sumber daya, sehingga mencari bahan mentah, tenaga kerja tidak terdidik yang murah, tenaga kerja terdidik, inovasi teknologi, infrastruktur fisik; dan (iii) mencari efisiensi sehingga mencari biaya sumber daya, produktifitas tenaga kerja, anggota integrasi yang kondusif untuk jaringan kerja, fasilitas bisnis yang terdiri dari promosi investasi, penyediaan jasa fasilitas pra dan pasca investasi, insentif investasi, sarana sosial(UNCTAD, 2000).

Berdasarkan latar belakang tersebut, maka permasalahan dalam penelitian ini adalah :

1. Bagaimana pengaruh PDB Riil, variabel fiskal (pajak penghasilan, pajak bumi dan bangunan, pajak penjualan, pengeluaran pemerintah untuk pembangunan, pengeluaran pemerintah untuk pendidikan, pengeluaran pemerintah untuk transportasi dan komunikasi) dan variabel dummy untuk krisis moneter terhadap penanaman modal asing langsung di Indonesia periode tahun 1980-2006 ?

2. Bagaimana kepekaan penanaman modal asing langsung terhadap PDB Riil, variabel fiskal dan krisis moneter di Indonesia periode tahun 1980-2006 ?

3. Bagaimana stabilitas model penanaman modal asing langsung di Indonesia periode tahun 1980-2006?

\section{Tujuan Penelitian}

Adapun tujuan penelitian ini adalah:

1. Untuk mengetahui besarnya pengaruh PDB Riil, variabel fiskal ( pajak penghasilan, pajak bumi dan bangunan, pajak penjualan, pengeluaran pemerintah untuk pembangunan, pengeluaran pemerintah untuk pendidikan, pengeluaran pemerintah untuk transportasi dan komunikasi ) dan variabel dummy untuk krisis moneter terhadap penanaman modal asing langsung di Indonesia periode tahun 1980-2006.

2. Untuk mengetahui besarnya kepekaan penanaman modal asing langsung terhadap PDB Riil, variabel fiskal dan 
krisis moneter di Indonesia periode tahun 1980-2006.

3. Untuk mengetahui tingkat stabilitas model penanaman modal asing langsung di Indonesia periode tahun 1980-2006.

\section{KERANGKA PEMIKIRAN DAN HIPOTESIS}

Pertumbuhan ekonomi didefinisikan sebagai proses dimana terjadi kenaikan pendapatan nasional. Definisi lain menyatakan pertumbuhan ekonomi terjadi bila ada kenaikan output perkapita. Jadi bisa dikatakan bahwa ukuran pertumbuhan ekonomi adalah pendapatan nasional (PDB).

Menurut M.L. Jhingan (1994), investasi digolongkan menjadi 2 yaitu: (1) Induced Investment, terjadi sebagai akibat dari pertambahan pendapatan uang di dalam masyarakat atau karena adanya pertambahan permintaan efektif; (2) Autonomous Investment yaitu investasi berdasarkan tabungan yang nyata dan merupakan penyebab pertambahan pendapatan (secara berlipat ganda karena adanya multiplier effect).

Menurut beberapa ahli ekonomi seperti Hymer, Vernon, Dunning, Stephen H. Hemmer (1988), yang menarik kesimpulan dari hipotesa maupun konsep teoritis yang mereka buat yaitu bahwa motivasi penanaman modal tetap merupakan fungsi pertimbangan dari beberapa variabel ekonomi yang mempengaruhi keputusan penanaman modal, baik secara makro maupun secara mikro.

Menurut Hollis Chenery (1960) apabila dilihat dari sisi negara penerima teori yang masuk dalam teori pembentukan penanaman modal asing langsung adalah teori "Kesenjangan Ganda (Two gap Model)". Teori ini sering digunakan sebagai justifikasi diterimanya bantuan luar negeri oleh negaranegara berkembang. ( Jhingan, 1994:484 )

Faktor-faktor yang mempengaruhi investasi asing yang mengalir ke suatu negara dapat kita lihat dari sudut pandang negara itu sendiri sebagai negara yang membutuhkan investasi asing, atau juga dapat dilihat dari sudut pandang investor asing yang akan menanamkan modalnya di negara bersangkutan, sehingga faktor tersebut akan mempengaruhi keputusan investor asing itu dalam menanamkan modalnya di Indonesia.

Beberapa faktor negara tuan rumah yang memiliki pengaruh terhadap investasi asing terdiri dari tiga faktor utama. Pertama, kerangka kebijakan untuk penanaman modal asing langsung yang terdiri dari stabilitas sosial ekonomi dan politik, peraturan mengenai cara masuk dan operasi, perlakuan standar untuk penanaman modal asing langsung, kebijakan struktur pasar (merger dan akuisisi), perjanjian internasional penanaman modal asing langsung, kebijakan privatisasi, kebijakan perdagangan (hambatan tariff dan non-tariff) dan kebijakan pajak. Kedua adalah faktor dari perusahaan yang terbagi atas (i) faktor mencari pasar sehingga mencari ukuran pasar dan pendapatan perkapita, pertumbuhan pasar, akses ke pasar regional dan internasional, keinginan konsumen, dan struktur pasar; (ii) mencari sumber daya, sehingga mencari bahan mentah, tenaga kerja tidak terdidik yang murah, tenaga kerja terdidik, inovasi teknologi, infrastruktur fisik; dan (iii) mencari efisiensi sehingga mencari biaya sumber daya, produktifitas tenaga kerja, anggota integrasi yang kondusif untuk jaringan kerja, fasilitas bisnis yang terdiri dari promosi investasi, penyediaan jasa fasilitas pra dan pasca investasi, insentif investasi, sarana sosial(UNCTAD, 2000).

Menurut Keynes (1985) pada hakikatnya beranggapan bahwa perekonomian selalu menghadapi masalah-masalah seperti pengangguran dan ketimpangan pendapatan masyarakat yang berakibat pada beban perekonomian bertambah, disini peran pemerintah yang aktif dalam perekonomian akan dapat membantu mengatasi masalahmasalah tersebut. Salah satu bentuk dari peran pemerintah yang dapat dilakukan adalah menjalankan kebijakan fiscal yaitu kebijakan terkait dengan kebijakan mengenai pajak dan pengeluaran pemerintah.

Untuk menjawab dan membahas dari semua permasalahan diatas, peneliti mengungkapkan hipotesis sebagai berikut : 
1. Diduga pengaruh PDB Riil, variabel fiskal ( pajak penghasilan, pajak bumi dan bangunan, pajak penjualan, pengeluaran pemerintah untuk pembangunan, pengeluaran pemerintah untuk pendidikan, pengeluaran pemerintah untuk transportasi dan komunikasi ) dan variabel dummy terhadap penanaman modal asing di Indonesia periode 1980-2006 adalah positif.

2. Diduga kepekaan penanaman modal asing langsung terhadap PDB Riil, variabel fiskal dan krisis moneter di Indonesia pada periode tahun 1980-2006 adalah inelstis.

3. Diduga stabilitas model penanaman modal asing di Indonesia periode 1980-2006 adalah tidak stabil.

\section{METODE PENELITIAN}

\section{Objek Penelitian}

Objek penelitian dalam penelitian ini adalah penanaman modal asing langsung (FDI), PDB riil ( GDP ), pajak penghasilan (ITAX ), pajak bumi dan bangunan (PTAX), pajak penjualan (STAX ), pengeluaran pembangunan ekonomi (ECO), pengeluaran transportasi dan komunikasi (TRANS ), pengeluaran pemerintah untuk pendidikan (EDU), serta krisis ekonomi di Indonesia periode 1980 - 2006 .

\section{Model Penelitian}

Model yang digunakan dalam penelitian ini adalah model ekonometrik yang dianalisa dengan menggunakan metode Ordinary Least Square (OLS) dengan Lin-Log Model dimana variabel tidak bebasnya dalam bentuk linear dan variabel bebasnya dalam bentuk logaritma. Penggunaan Lin-Log Model ini dikarenakan scatter plot yang menggambarkan hubungan antara variabel bebas dan tidak bebasnya menunjukkan adanya beberapa hubungan yang tidak linear. Berdasarkan uraian diatas, penulis mencoba menggunakan model yang dibangun oleh Assahinur (2003) dengan melakukan modifikasi pada model penelitiannya, maka didapat persamaan sebagai berikut : $\log \mathrm{FDI}_{\mathrm{t}}=\beta_{0}+\beta_{1} \log \mathrm{GDP}_{\mathrm{t}}+\beta_{2} \log \mathrm{ITAX}_{\mathrm{t}}+\beta_{3}$ $\log$ BTAX $_{t}+\beta_{4} \log$ STAX $_{t}$

$+\beta_{5} \operatorname{logECO} \mathrm{E}_{\mathrm{t}}+\beta_{6} \log \mathrm{TRANS}_{\mathrm{t}}+$

$\beta_{7} \log \mathrm{EDU}_{\mathrm{t}}+\beta_{8} \mathrm{D}_{\mathrm{t}}+\mathrm{U}_{\mathrm{t}}$

Dimana :

FDI $=$ Penanaman modal asing langsung $(F D I)$

GDP $=$ PDB $($ Produk Domestik

Bruto) riil

ITAX $=$ Pajak penghasilan sebagai rasio dari total pendapatan pemerintah

BTAX = Pajak bumi dan bangunan sebagai rasio dari total pendapatan pemerintah STAX $=$ Pajak penjualan sebagai rasio dari total pendapatan pemerintah

$\mathrm{ECO}=$ Pengeluaran untuk pembangunan sebagai rasio dari total pengeluaran pemerintah

TRANS = Pengeluaran untuk transportasi jalan dan total pengeluaran pemerintah EDU = Pengeluaran untuk pendidikan sebagai rasio dari total pengeluaran pemerintah

D = Dummy variabel untuk krisis ekonomi dan keuangan

$\beta_{0}, \beta_{1}, \ldots \beta_{8}=$ Koefisien Regresi

$\mathrm{E}_{\mathrm{t}} \quad=$ Error Term

\section{Alat Analisis}

a) Analisis koefesien korelasi (R)

Yaitu untuk melihat besarnya hubungan antara variabel bebas dan variabel terikat.

b) Koefesien Determinasi $\left(\mathrm{R}^{2}\right)$

Koefesien determinasi digunakan untuk mengetahui seberapa besar pengaruh variabel bebas

dalam menerangkan secara keseluruhan terhadap variabel terikat.

\section{Alat Pengujian}

a) Uji Signifikan

1) Uji $t$ dilakukan untuk melihat signifikansi dari pengaruh variabel bebas secara individu terhadap variabel terikat, dengan asumsi variabel bebas lainnya konstan. 
2) Uji F dilakukan untuk melihat pengaruh variabel bebas terhadap variabel terikat secara bersama-sama, signifikan atau tidaknya dapat dianalisa dengan $\mathrm{F}$ statistik.

3) Pengujian Asumsi klasik

a) Uji Durbin Watson (DW) digunakan untuk mengetahui ada atau tidak adanya auto korelasi dalam model regresi. Auotokorelasi merupakan korelasi (hubungan) yang terjadi diantara anggota-anggota dari serangkaian pengamatan yang tersusun dalam rangkaian hipotesis.

b) Uji Multikolineritas

Multikolinier menunjukan gejala adanya hubungan linear atau hubungan yang pasti diantara variabel penjelas dalam model regresi. Gejala ditunjukan oleh beberapa faktor, namun yang paling mendukung penjelasan adanya multikolinier dalam model yaitu apabila nilai $\mathrm{R}^{2}$ dari hasil regresi sangat tinggi namun sebagian besar variabel penjelas tidak menjelaskan hubungan yang signifikan terhadap variabel yang dijelaskan, melalui perbandingan antara nilai t-stat dan F-stat dengan t-tabel dan Ftabel.

c) Uji Heteroskedastis

Heteroskedastis terjadi apabila variabel gangguan tidak mempunyai varians yang sama untuk semua observasi. Akibat dari adanya heteroskedastis, penaksiran OLS tetap tidak bias tetapi tidak efesien. Alat pendeteksi yang akan digunakan penulis adalah dengan menggunakan test white, yaitu membandingkan obs R-squared probability yang lebih kecil $(<)$ dari $(0,5)$ berarti tidak terjadi heteroskedastis, dan penulis menggunakan alat test Eviews.

\section{HASIL PENELITIAN DAN PEMBAHASAN}

Dari hasil penelitian, diperoleh data FDI, PDB RIIL, PPH, PBB, PPN, ECO, TRANS, EDU, dan Variabel DUMMY di Indonesia Periode tahun1980-2006. adapun nilai masing-masing variabel dapat dilihat pada tabel dibawah. 
Tabel 1. Data Penanaman Modal Asing (FDI), PDB Riil, Pajak Penghasilan (PPH), Pajak Bumi dan Bangunan (PBB), Pajak Penjualan (PPN), Pengeluaran Pembangunan Ekonomi (ECO), Pengeluaran Pemerintah untuk Transportasi dan Komunikasi (TRANS), Pengeluaran Pemerintah untuk Pendidikan (EDU) serta Krisis Ekonomi (D) di Indonesia

Periode Tahun 1980 - 2006

\begin{tabular}{|c|c|c|c|c|c|c|c|c|c|}
\hline TAHUN & FDI & PDB RIIL & $\mathrm{PPH}$ & PBB & PPN & ECO & TRANS & EDU & $\mathrm{D}$ \\
\hline 1980 & 662.59 & 143769.8 & 3033.32 & 243.96 & 1258.01 & 13646.43 & 2061.9 & 1769.44 & 0 \\
\hline 1981 & 448.694 & 153022 & 3413.58 & 241.63 & 1350.9 & 15863.24 & 2094.12 & 1787.66 & 0 \\
\hline 1982 & 744.98 & 149871.1 & 3880.36 & 244.97 & 1589.7 & 19268.18 & 2053.81 & 1906.69 & 0 \\
\hline 1983 & 1241.12 & 166115 & 4014.15 & 268.79 & 1712.56 & 19515.27 & 2921.13 & 2056.62 & 0 \\
\hline 1984 & 922.08 & 176403.5 & 4018.19 & 292.44 & 1678.48 & 19700.12 & 2815.4 & 1970.97 & 0 \\
\hline 1985 & 1300.11 & 182047.7 & 4190.15 & 304.92 & 3634.7 & 19923.24 & 2719.44 & 2295.66 & 0 \\
\hline 1986 & 1480.28 & 187831 & 3988.48 & 322.28 & 4819.3 & 15676.4 & 2131.47 & 1674.06 & 0 \\
\hline 1987 & 2404.215 & 207230.3 & 4067.32 & 405.93 & 5414.3 & 14702.76 & 2369.61 & 1752.43 & 0 \\
\hline 1988 & 7676.12 & 221583.2 & 5359.36 & 572.58 & 6314.64 & 17110.71 & 2823.29 & 2220.36 & 0 \\
\hline 1989 & 8479.684 & 249836.2 & 7099.7 & 763.08 & 7657.23 & 18695.44 & 3835.57 & 2130.99 & 0 \\
\hline 1990 & 16633.94 & 272138.7 & 8309.04 & 975.35 & 9106.94 & 20168.13 & 4593.8 & 2485 & 0 \\
\hline 1991 & 17482.19 & 294857.2 & 10467.27 & 1039.8 & 10097.47 & 24038.89 & 6103.43 & 2823.32 & 0 \\
\hline 1992 & 21321.08 & 309762.6 & 12427.75 & 1153.95 & 11262 & 28103.46 & 7018.87 & 3156.09 & 0 \\
\hline 1993 & 17179.2 & 329776.1 & 14433 & 1425.75 & 11890 & 28047.5 & 7056.75 & 2789 & 0 \\
\hline 1994 & 52193.46 & 352229.4 & 16201.3 & 1481.37 & 14264.69 & 27762.21 & 6045.28 & 2714.16 & 0 \\
\hline 1995 & 92123.13 & 382746.3 & 17133.79 & 1539.78 & 15179.27 & 24638.79 & 5025.65 & 2483.35 & 0 \\
\hline 1996 & 71326.53 & 415370.5 & 19927.05 & 1780.8 & 15515.32 & 25794.53 & 5099.63 & 2892.6 & 0 \\
\hline 1997 & 157321.1 & 458679.5 & 23790.2 & 1888.22 & 17528.16 & 27637.71 & 4991.11 & 3251.23 & 0 \\
\hline 1998 & 108843.9 & 443047.5 & 21124.24 & 1405.74 & 12789.23 & 36734.33 & 4146.07 & 3443.43 & 1 \\
\hline 1999 & 77159.9 & 423082.1 & 20593.73 & 1315.24 & 12246.59 & 32703.27 & 3358.84 & 3223.04 & 1 \\
\hline 2000 & 147888.7 & 1389770 & 26274.22 & 1994.07 & 16040.63 & 17362.4 & 1975.69 & 2778.95 & 1 \\
\hline 2001 & 156456.6 & 1442985 & 94600 & 6700.66 & 55900.55 & 41600.33 & 6160.1 & 9701.2 & 1 \\
\hline 2002 & 87112.25 & 1506124 & 101900 & 7800.02 & 65200.01 & 37300.13 & 9651.1 & 11307.1 & 1 \\
\hline 2003 & 111798.9 & 1577171 & 114800 & 10900.12 & 76800.43 & 67700.67 & 9817.5 & 15058.4 & 1 \\
\hline 2004 & 95476.12 & 1656517 & 133300 & 14700.14 & 87500.33 & 68400.21 & 10616.1 & 15339.1 & 1 \\
\hline 2005 & 133484.5 & 1750815 & 175380 & 16184.11 & 101295.5 & 175749.5 & 13149.4 & 25988.1 & 1 \\
\hline 2006 & 140927.6 & 1847293 & 208834 & 20684.22 & 123028.2 & 185812.1 & 17912.2 & 34287.7 & 1 \\
\hline
\end{tabular}

Sumber : Statistik Ekonomi dan Keuangan Indonesia (SEKI) Bank Indonesia

Hasil analisis menunjukkan bahwa nilai koefisien korelasi (R) sebesar 0,944530 yang berarti hubungan timbal balik antara seluruh variabel independen dan variabel dependen adalah erat, karena nilai tersebut mendekati satu. Sedangkan nilai koefisien determinasi ( $\mathrm{R}^{2}$ ) adalah. 0.961598 yang berarti bahwa varians dari variabel-variabel bebas didalam model yaitu PDB riil, pajak penghasilan (income tax), pajak bumi dan bangunan (property tax), pajak penjualan (sales tax), pengeluaran pemerintah untuk pendidikan, pengeluaran pemerintah untuk transportasi, pengeluaran pemerintah untuk pembangunan ekonomi dan dummy untuk krisis ekonomi, dapat menerangkan $96,16 \%$ dari variabel tidak bebasnya yaitu penanaman modal asing langsung, sedangkan sisanya sebesar 3,84\% dipengaruhi oleh variabel lain diluar model.

Untuk melihat tingkat signifikasi pengaruh variabel bebas terhadap variabel terikat secara bersama-sama, dapat dilihat dari nilai $\mathrm{F}$ hitung sebesar 56,34059 dengan $\mathrm{F}$ table pada tingkat keyakinan 95\% adalah 2,51. Berdasarkan hasil perhitungan diatas, maka dapat dilihat bahwa $\mathrm{F}$ hitung $>\mathrm{F}$ table atau 56,34059 > 2.51 artinya bahwa beberapa variabel ekonomi (PDB Riil, Pajak Penghasilan, Pajak Bumi dan Bangunan, , Pengeluaran Pemerintah Untuk Pembangunan Ekonomi, Pengeluaran Pemerintah Untuk Transportasi dan Komunikasi, Pengeluaran Pemerintah Untuk 
Pendidikan, Variabel dummy untuk krisis ekonomi ) secara bersama-sama signifikan mempengaruhi penanaman modal asing langsung Indonesia di Indonesia periode 1980 - 2006 pada tingkat signifikansi sebesar $1 \%$.

Untuk analisis autokorelasi digunakan uji Durbin-Watson pada tingkat keyakinan 95\% sehingga diperoleh nilai Durbin-Watson statistik sebesar 1.970183 yaitu berada di daerah tidak terdapat korelasi. Untuk analisis multikolinierity test diperoleh nilai (AC) tidak lebih dari 0.05. Berdasarkan analisis Corelogram of Residuals maka dapat disimpulkan bahwa model yang dipakai tidak terdapat Multikolinieritas dalam model regresi. Hal ini bisa dilihat dengan nilai Auotocorrelation (AC) tiap variabel lebih 0.05 .

Pengaruh PDB Riil, variabel fiskal ( pajak penghasilan, pajak bumi dan bangunan, pajak penjualan, pengeluaran pemerintah untuk pembangunan, pengeluaran pemerintah untuk pendidikan, pengeluaran pemerintah untuk transportasi dan komunikasi ) dan variabel dummy terhadap penanaman modal asing di Indonesia periode 1980-2006:

1) Hubungan antara Penanaman Modal Asing Langsung dengan Produk Domestik Bruto Riil

Variabel Produk Domestik Bruto Riil
(PDB riil) koefisiennya menunjukkan
koefisien yang negatif dan tidak signifikan
terhadap penanaman modal asing langsung.
Nilai koefisien PDB riil sebesar -0.142884
berarti setiap kenaikan PDB riil turun sebesar
1\%, ceteris paribus, akan meningkatkan
penanaman modal langsung asing yang masuk
sebesar 0.142884\%. Walaupun hubungannya
negatif akan tetapi tidak signifikan dan nilai
koefisiennya pun sangat kecil, ini berarti
pengaruh negatif PDB Riil tersebut terhadap
penanaman modal asing langsung tidak
berarti. Hal ini dikarenakan PDB Riil
sebetulnya memiliki hubungan yang yang
positif dengan FDI. Hubungan positif ini
sesuai dengan penelitian K.C. Fung, Hitomi
lizaka, dan Alan Siu (2003) yang

menyebutkan bahwa hubungan positif ini disebabkan karena PDB riil merupakan gambaran ukuran pasar atau kapabilitas pasar suatu negara. Semakin besarnya pendapatan (PDB riil) suatu negara merupakan bukti bahwa negara tersebut memiliki ukuran pasar atau kapabilitas pasar lebih besar yang secara potensial dapat mendukung penjualan produknya di negara tersebut, dimana salah satu tujuan investasi asing ke suatu negara untuk menjadikannya pasar bagi produknya. Jadi, semakin besar tingkat pendapatan suatu negara, maka semakin menjanjikan pula negara sebagai negara penerima investasi asing.

\section{2) Hubungan antara Penanaman Modal Asing Langsung dengan Pajak Penghasilan}

Variabel pajak penghasilan mempunyai koefisien yang positif dan signifikan terhadap penanaman modal asing langsung. Nilai koefisien 1.843601 berarti bahwa setiap kenaikan penerimaan pajak penghasilan sebesar $1 \%$, ceteris paribus, maka akan menambah penanaman modal asing langsung sebesar $1,843601 \%$. Apabila penerimaan dari pajak penghasilan meningkat maka akan memberikan respon positif terhadap pertumbuhan ekonomi. Hal ini terjadi karena dengan peningkatan pada pendapatan Negara, akan menambah kegiatan perekonomian sehingga dapat menciptakan lapangan pekerjaan yang lebih luas. Selain itu dapat melengkapi sarana dan prasarana Negara dengan harapan dapat mempercepat pertumbuhan untuk mencapai kemakmuran bagi masyarakat. Hal ini akan menjadi daya tarik bagi para investor untuk menanamkan modalnya di Indonesia. Dengan catatan pemerintah mampu menumbuhkan kepercayaan pada para investor sehingga mereka berani berinvestasi di Indonesia. Hal ini dapat menjelaskan hubungan antara pajak penghasilan dan penanaman modal asing yang positif.

3) Hubungan antara Penanaman Modal Asing Langsung dengan Variabel Pajak Bumi dan Bangunan 
Variabel pajak bumi dan bangunan memiliki koefisien yang positif dan tidak signifikan terhadap penanaman modal asing langsung. Nilai koefisien sebesar 0.541731 menunjukkan bahwa setiap kenaikan penerimaan pajak bumi dan bangunan sebesar $1 \%$, ceteris paribus, akan menyebabkan kenaikan penanaman modal asing langsung sebesar 0,541731\%. Hubungan yang tidak signifikan antara variabel pajak bumi dan bangunan dengan penanaman modal asing langsung ini diluar ekspektasi awal. Hal ini diduga akibat penerimaan pajak bumi dan bangunan, meskipun relatif kecil dan tidak sebesar penerimaan pajak penghasilan dan pajak penjualan, dibagikan antara antara berbagai tingkat pemerintahan yaitu pemerintah pusat dan pemerintah daerah, seperti yang tertera dalam PERPU No.11 Tahun 1959 tentang Pajak Hasil Bumi, UU No.12 Tahun 1985, dan juga diatur dalam UU No. 12 Tahun 1994. Dalam UU No.12 Tahun 1985 dan UU No. 12 Tahun 1994 penerimaan pajak bumi dan bangunan dibagi sebagai berikut : pemerintah pusat $10 \%$ dan sekurang-kurangnya $90 \%$ untuk pemerintah daerah tingkat I dan II sebagai pendapatan daerah yang bersangkutan. Dengan memperhatikan pembagian tersebut terlihat bahwa hasil penerimaan pajak bumi dan bangunan diarahkan untuk kepentingan masyarakat terutama masyarakat daerah. Peningkatan pendapatan pemerintah daerah ini tentunya akan menambah kemampuan pemerintah tersebut untuk membangun daerahnya dengan pengeluaran untuk infrastruktur-infrastruktur sehingga berkembangnya perekonomian di daerah tersebut. Selain itu apabila kebutuhan pembangunan sudah terpenuhi, penanaman modal asing tidak terlalu dibutuhkan. Hal ini sama seperti peningkatan yang terjadi pada penerimaan pajak penghasilan. Negara akan sedikit lebih mandiri dan tidak selalu bergantung kepada pinjaman luar negeri karena tercukupinya semua kebutuhan yang menunjang kesejahteraan masyarakat. Dengan catatan penerimaan pendapatan Negara meningkat secara signifikan dan stabil.

\section{4) Hubungan antara Penanaman Modal Asing Langsung dengan Variabel Pajak Penjualan}

Variabel pajak penjualan memiliki koefisien yang positif namun tidak signifikan terhadap penanaman modal asing langsung. Nilai koefisien sebesar 0.721037 menunjukkan bahwa tiap pertambahan penerimaan pajak penjualan sebesar $1 \%$, ceteris paribus, maka menyebabkan peningkatan penanaman modal asing langsung sebesar $0,721037 \%$. Seperti halnya penerimaan pajak yang semakin meningkat akan menarik minat para investor untuk menanamkan modalnya di Indonesia, begitu halnya dengan penerimaan pajak penjualan yang dapat menarik para investor. Apabila peningkatan penerimaan pajak terjadi akan memberikan sumbangan yang positif bagi perekonomian karena dengan pengalokasian yang tepat sasaran dapa mempercepat pertumbuhan ekonomi. Karena dengan adanya investor yang masuk ke Indonsia setidaknya memberikan pemasukan dari keuntungan usaha yang dibuat di Indonesia. Indonesia dapat mengatasi kekurangan dana pembangunan, selain itu Negara kita bisa sharing pengetahuan dan teknologi yang terdepan yang akan membuahkan keuntungan. Paling tidak adanya hubungan kerjasama antara Indonesia dengan Negara lain.

\section{5) Hubungan antara Penanaman Modal Asing Langsung dengan Variabel Pengeluaran Pemerintah Untuk Pembangunan Ekonomi}

Variabel pengeluaran pemerintah untuk pembangunan ekonomi memiliki koefisien yang positif dan signifikan terhadap penanaman modal asing langsung. Nilai koefisien pengeluaran pembangunan sebesar 1.242996 menunjukkan bahwa setiap kenaikan setiap kenaikan $1 \%$ pengeluaran pembangunan, ceteris paribus, akan menyebabkan peningkatan penanaman modal asing langsung sebesar 1,242996\%. Hal ini membuktikan pembangunan infrastruktur secara keseluruhan yaitu melalui pembangunan sarana dan prasarana secara 
keseluruhan berpengaruh positif terhadap penanaman modal asing langsung di Indonesia. Hubungan positif antara pengeluaran pembangunan ekonomi dengan penanaman modal asing langsung ini sesuai dengan oleh penelitian Jo Hui Chen (2002).

6) Hubungan antara Penanaman Modal Asing Langsung dengan Variabel Pengeluaran Pemerintah Transportasi dan Komunikasi.

Variabel pengeluaran pemerintah untuk transportasi dan komunikasi memiliki koefisien yang negatif dan tidak signifikan terhadap penanaman modal asing langsung. Koefisien sebesar $\quad-0.027034$ menunjukkan bahwa setiap kenaikan pengeluaran pemerintah untuk transportasi dan komunikasi sebesar $1 \%$, cateris paribus, akan menyebabkan penurunan penanaman modal asing sebesar $0,027034 \%$. Walaupun hubungannya negatif akan tetapi tidak signifikan dan nilai koefisiennyapun sangat kecil, ini berarti pengaruh negative pengeluaran pemerintah untuk transportasi dan komunikasi tersebut terhadap penanaman modal asing langsung tidak berarti. Hal ini dikarenakan variabel pengeluaran pemerintah untuk transportasi dan komunikasi sebetulnya memiliki hubungan yang yang positif dengan FDI. Pengeluaran pemerintah tersebut dialokasikan oleh pemerintah untuk membangun dan melengkapi sarana dan prasarana untuk memfasilitasi para investor asing di Indonesia. Hal ini menjadi salah satu hal yang menarik bagi mereka sehingga dapat memberikan kenyamanan serta kemudahan dalam melakukan akses sesuai dengan kebutuhannya. Selain itu dengan pembangunan keseluruhan infrastruktur akan mendukung kelancaran operasi suatu perusahaan dan tentunya akan sangat bermanfaat. Ini akan memberikan manfaat juga bagi Negara, karena dengan investasi asing dapat menggali dan memanfaatkan potensi ekonomi, menyediakn kesempatan kerja dan meningkatkan kemakmuran rakyat.

\section{7) Hubungan antara Penanaman Modal Asing Langsung dengan Variabel}

\section{Pengeluaran Pemerintah Untuk Pendidikan}

Variabel pengeluaran pemerintah untuk pendidikan memiliki koefisien yang negatif terhadap penanaman modal asing langsung. Koefisien sebesar -3.837237 menunjukkan bahwa setiap kenaikan pengeluaran pemerintah untuk pendidikan $1 \%$, cateris paribus, akan penurunan penanaman modal asing langsung sebesar $3,837237 \%$. Hubungan antara kedua variabel ini secara statistik sangat signifikan. Pengeluaran pemerintah untuk pendidikan berpengaruh negative dan sangat signifikan terhadap penanaman modal asing langsung. Hal ini terjadi karena apabila kebutuhan pendidikan telah terpenuhi dan mecetak sumber daya manusia yang berkualitas, investasi asing tidak akan diperlukan lagi. Meningkatnya kualitas pendidikan akan mendorong perekonomian Negara, karena akan melahirkan tenaga kerja yang baik dan dapat bersaing dengan tenaga kerja Negara lain yang berkualitas tinggi. Apabila hal itu terjadi, diekspektasikan akan muncul pemikiran-pemikiran yang brilian serta dapat menciptakan karya-karya baru yang mengarah kepada peningkatan teknologi yang paling tidak sama dengan Negara-negara maju.

\section{8) Hubungan antara Penanaman Modal Asing Langsung dengan Variabel Dummy Krisis Ekonomi}

Variabel dummy krisis ekonomi memiliki koefisien yang positif dan tidak signifikan. Koefisien sebesar 0.395947 dengan tingkat kepercayaan 95\% menunjukkan krisis ekonomi menyebabkan peningkatan penanaman modal asing langsung yang tidak signifikan. Artinya bahwa kenaikan tersebut tidak berarti, selain itu nilai koefisiennyapun kecil. Hal ini telah terbukti dimana krisis ekonomi yang dimulai krisis nilai tukar akibat krisis yang melanda Asia turut melemahkan nilai tukar rupiah terhadap dolar AS. Turunnya nilai tukar menyebabkan jumlah hutang luar negeri pemerintah dan sektor swasta makin membengkak. Hal ini tentu berdampak 
negatif terhadap posisi neraca pembayaran. Pada saat keseimbangan eksternal tergangggu, terjadi pula ketidak-seimbangan internal dimana terjadi kenaikan harga barang-barang sehingga memperbesar angka inflasi. Efek krisis nilai tukar terus menyebar ke sektorsektor lainnya hingga menimbulkan pertumbuhan ekonomi tahunan (PDB riil) turun.

Penurunan perekonomian menyebabkan penurunan arus modal asing. Namun hal tersebut bukanlah satu-satunya alasan penurunan tersebut. Tidak adanya jaminan mengenai prakondisi-prakondisi yang dibutuhkan oleh investor terutama instabilitas sosial politik dan keamanan. Kerusuhan yang menyudutkan etnis tertentu serta aksi masa yang menuntut referendum dan juga konflikkonflik sosial lainnya telah menyebabkan jumlah investasi asing yang masuk lebih kecil dari yang keluar. Jadi stabilitas ekonomi, sosial politik dan keamanan merupakan jaminan bagi investor dalam kelancaran usahanya.

\section{Nilai Koefisien Regresi}

Berdasarkan persamaan tersebut diatas diperoleh nilai-nilai koefisien regresi yang dapat menunjukan elastisitas. Masing-masing nilai koefisien tersebut akan dijelaskan sebagai berikut :

1. Elastisitas penanaman modal asing terhadap PDB Riil adalah inelastis dengan arah hubungan yang negatif dengan nilai koefisien sebesar -0.142884 $(\mathrm{E}<1)$. Koefisien PDB Riil yang negatif namun tidak signifikan menunjukkan bahwa ketika terjadi penurunan PDB Riil sebesar $1 \%$ (ceteris paribus), maka penanaman modal asing akan naik sebesar 0,142884 $\%$.

2. Elastisitas penanaman modal asing terhadap pajak penghasilan adalah elastis dengan arah hubungan yang positif dengan nilai koefisien sebesar 1.843601 (E > 1). Koefisien pajak penghasilan yang positif menunjukkan bahwa ketika terjadi peningkatan pajak penghasilan sebesar 1 $\%$ (ceteris paribus), maka penanaman modal asing akan naik sebesar $1.843601 \%$.

3. Elastisitas penanaman modal asing terhadap pajak bumi dan bangunan adalah inelastis dengan arah hubungan yang positif dengan nilai koefisien sebesar $0.541731(\mathrm{E}<1)$. Koefisien pajak bumi dan bangunan yang positif menunjukkan bahwa ketika terjadi peningkatan pajak bumi dan bangunan sebesar $1 \%$ (ceteris paribus), maka penanaman modal asing akan naik sebesar $0.541731 \%$.

4. Elastisitas penanaman modal asing terhadap pajak penjualan adalah inelastis dengan arah hubungan yang positif dengan nilai koefisien sebesar 0.721037 $(\mathrm{E}<1)$. Koefisien pajak penjualan yang positif menunjukkan bahwa ketika terjadi peningkatan pajak penjualan sebesar $1 \%$ (ceteris paribus), maka penanaman modal asing akan naik sebesar $0.721037 \%$.

5. Elastisitas penanaman modal asing terhadap pengeluaran pemerintah untuk pembangunan adalah elastis dengan arah hubungan yang positif dengan nilai koefisien sebesar 1.242996 (E > 1). Koefisien pengeluaran pemerintah untuk pembangunan ekonomi yang positif menunjukkan bahwa ketika terjadi peningkatan pengeluaran pemerintah untuk pembangunan ekonomi sebesar $1 \%$ (ceteris paribus), maka penanaman modal asing akan naik sebesar $1.242996 \%$.

6. Elastisitas penanaman modal asing terhadap pengeluaran pemerintah untuk transportasi dan komunikasi adalah inelastis dengan arah hubungan yang negatif dengan nilai koefisien sebesar $0.027034(\mathrm{E}<1)$. Koefisien yang negatif menunjukkan bahwa ketika terjadi peningkatan pengeluaran pemerintah untuk transportasi dan komunikasi sebesar $1 \%$ (ceteris paribus), maka penanaman modal asing akan turunsebesar $0.027034 \%$.

7. Elastisitas penanaman modal asing terhadap pengeluaran pemerintah untuk pendidikan adalah inelastis dengan arah hubungan yang negatif dengan nilai 
koefisien sebesar -3.837237 ( $<1)$. Koefisien pengeluaran pemerintah untuk pendidikan yang negatif menunjukkan bahwa ketika terjadi peningkatan pengeluaran pemerintah untuk pendidikan sebesar $1 \%$ (ceteris paribus), maka penanaman modal asing akan turun sebesar $3.837237 \%$.

8. Elastisitas penanaman modal asing terhadap variabel dummy untuk krisis moneter adalah inelastis dengan arah hubungan yang positif dengan nilai koefisien sebesar 0.395947 ( $\mathrm{E}<1)$. Koefisien yang positif menunjukkan bahwa ketika terjadi peningkatan variabel dummy untuk krisis moneter sebesar $1 \%$ (ceteris paribus), maka penanaman modal asing akan naik sebesar $0.395947 \%$

\section{PENUTUP}

\section{Kesimpulan}

Berdasarkan hasil dan pembahasan pada bab sebelumnya, maka penulis dapat mengambil kesimpulan sebagai berikut :

1. Variabel PDB riil memiliki pengaruh negatif akan tetapi tidak signifikan terhadap penanaman modal asing langsung. Walaupun hubungannya negatif akan tetapi tidak signifikan dan nilai koefisiennyapun sangat kecil, ini berarti pengaruh negative PDB Riil tersebut terhadap penanaman modal asing langsung tidak berarti. Hal ini dikarenakan PDB Riil sebetulnya memiliki hubungan yang yang positif dengan FDI. Dan hal ini menunjukkan motivasi investor asing menanamkan modalnya ke Indonesia salah satunya ialah menjadikan Indonesia sebagai pasar bagi produk-produknya.

Pajak penghasilan pajak bumi dan bangunan dan pajak penjualan berpengaruh positif terhadap penanaman modal asing langsung, hal ini dikarenakan apabila semakin tinggi penerimaan yang diperoleh pemerintah dari pajak penghasilan dan pajak penjualan, maka akan meningkatkan pula pendapatan pemerintah yang tentunya akan dialokasikan untuk peningkatan perekonomian sehingga dapat mencapai apa yang menjadi tujuan negara kita. Apabila perekonomian negara semakin meningkat dan stabil maka hal inilah yang menjadi daya tarik bagi para investor untuk menanamkan modalnya di Indonesia. Selain itu akan memberikan sumbangan terhadap pertumbuhan ekonomi. Karena semakin tinggi penerimaan pemerintah maka akan mendukung perekonomian Negara serta akan terpenuhinya kebutuhan untuk pembangunan Negara. Sehingga pinjaman dari luar tidak diperlukan lagi. Apabila kondisi ini berlangsung dalam jangka waktu yang cukup lama dan menyebabkan perekonomian yang semakin berkembang dengan stabil, maka Indonesia akan mampu bersaing dengan Negara lain. Selain itu tidak menutup kemungkinan akan merubah status Negara dari Negara berkembang menjadi Negara maju.

Pengeluaran pemerintah untuk pembangunan ekonomi memiliki hubungan yang positif dan signifikan terhadap FDI. Tentu saja hal ini terjadi karena pengeluaran pemerintah tersebut dialokasikan untuk kebutuhan pembangunan menuju kearah yang lebih baik sehingga akan menjadi daya tarik bagi investor. Pengeluaran pemerintah untuk transportasi dan komunikasi memiliki koefisien negatif dan tidak signifikan. Walaupun hubungannya negatif akan tetapi tidak signifikan dan nilai koefisiennyapun sangat kecil, ini berarti pengaruh negative pengeluaran pemerintah untuk transportasi dan komunikasi tersebut terhadap penanaman modal asing langsung tidak berarti. Hal ini dikarenakan variabel pengeluaran pemerintah untuk transportasi dan komunikasi sebetulnya memiliki hubungan yang yang positif dengan FDI. Diduga karena pengeluaran tersebut dialokasikan oleh pemerintah untuk membangun dan melengkapi sarana dan prasarana untuk memfasilitasi para investor asing di Indonesia. Pengeluaran pemerintah untuk pendidikan berpengaruh 
negative dan sangat signifikan terhadap penanaman modal asing langsung. Hal ini terjadi karena apabila kebutuhan pendidikan telah terpenuhi dan mecetak sumber daya manusia yang berkualitas, investasi asing tidak akan diperlukan lagi. Meningkatnya kualitas pendidikan akan mendorong perekonomian Negara, karena akan melahirkan tenaga kerja yang baik dan dapat bersaing dengan tenaga kerja Negara lain yang berkualitas tinggi. Apabila hal itu terjadi, diekspektasikan akan muncul pemikiran-pemikiran yang brilian serta dapat menciptakan karyakarya baru yang mengarah kepada peningkatan teknologi yang paling tidak sama dengan Negara-negara maju.

2. Elastisitas penanaman modal asing terhadap PDB Riil ( $G D P$ ), pengeluaran pemerintah untuk transportasi ( Trans) dan pengeluaran pemerintah untuk pendidikan ( education) adalah bersifat inelastis dengan arah hubungan yang negatif. Adapun elastisitas penanaman modal asing terhadap pajak bumi dan bangunan ( property tax ), pajak penjualan ( selling tax) dan variabel dummy untuk krisis moneter adalah bersifat inelastis dengan arah hubungan yang positif. Sedangkan elastisitas penanaman modal asing terhada pajak penghasilan ( income tax ) dan pengeluaran pemerintah untuk pembangunan ekonomi ( economic) adalah bersifat elastis dengan arah hubungan yang positif.

3. Stabilitas model penanaman modal asing di Indonesia periode tahun 1980-2006 adalah stabil. Indonesia sempat dilanda krisis ekonomi akan tetapi hal ini dapat diatasi, terbukti dengan meningkatnya FDI di Indonesia walaupun naik turun tapi memberikan peningkatan dalam perekonomian Indonesia. Sehingga dapat dijelaskan bahwa model penanaman modal asing di Indonesia periode tahun 1980-2006 adalah stabil.

\section{Saran}

Mengacu pada penelitian ini, ada beberapa strategi yang kiranya harus dipertimbangkan. Pertama, pertubuhan FDI yang semakin pesat baik secara global maupun di Kawasan Asia menunjukkan bahwa potensi sumber pembiayaan asing ini relative besar dan masih terbuka, maka pemerintah dalam hal ini harus menjadikannya motivasi dalam memperbaiki sistem perekonomian Negara dengan cepat dan cekatan karena persaingan semakin ketat. Apabila Negara kita hanya selalu pada posisi seperti sekarang ini, Indonesia akan tertinggal jauh dari Negara-negara berkembang lainnya. Pembangunan yang dilakukan pemerintah seharusnya pembangunan yang tepat sasaran dan berujung pada kesejahteraan masyarakat. Karena hal itulah yang paling penting dan menjadi tujuan yang ingin dicapai oleh setiap Negara.

Kedua, perkembangan FDI yang semakin meningkat menuntut adanya perbaikan dalam segala aspek baik ekonomi maupun non ekonomi. Dalam hal ini yang perlu diperhatikan adalah menyangkut perbaikan political risk, kondisi perekonomian dan perbaikan variabel ekonomi makro. Kajian yang lebih komprehensif perlu dilakukan guna mengetahui permasalahan sesungguhnya dihadapi, sehingga penentuan strategi kebijakan investasi tidak akan tertinggal dari Negara lain. Hal inilah yang menjadi daya tarik bagi para investor asing untuk menanamkan modalnya.

Ketiga, untuk mendorong lebih lanjut peningkatan investasi dan usaha yang lebih menarik yaitu memberikan kepastian hukum atas peraturan-peraturan pada tingkat pusat dan daerah serta menghasilkan produk hukum yang berkaitan dengan kegiatan penanaman modal sehingga tidak memberatkan beban tambahan pada biaya produksi usaha dan memberikan kemudahan yang paling mendasar atas pelayanan yang ditujukan pada para investor, meliputi perijinan investasi, imigrasi, kepabeaan, perpajakan dan pertahanan wilayah.

\section{DAFTAR PUSTAKA}

10.22202/economica.2012.v1.i1.113 
Aditiawan. (2007). Ekonomi Makro, PMA/PMDN, Taktik Pembangunan, Teknologi. Erlangga, Jakarta

A Tony Prasentiantono. (1992). Kebijakan Ekonomi Publik di Indonesia (Substansi dan Urgensi), kumpulan tulisan Guritno Mangkoesoebroto, PT Gramedia Pustaka

Faisal Basri. (1995). Perekonomian Indonesia Menjelang Abad XXI, Penerbit Erlangga.

Fung, K.C., Hitomi lizaka, Alan Siu. (2003). U.S. and Japanese Direct Investment in China : An Econometric Examination, University of California, Barkeley.

Gujarati, Damodar N. (1995). Basic Econometrics, Third Edition. McGraw-Hill Inc. New York.

Jhingan, M.L. (1994). Ekonomi Pembangunan dan Perencanaan, Cetakan 5, Raja Grafindo Persada, Jakarta.

Krugman, Paul. R., Maurice Obstefld. (2000). International Economics, Fifth Edition, Addison-Wesley Publishing Company, Inc, New York.

Mudrajat Kuncoro (1989), "Dampak Arus Modal Asing Terhadap Pertumbuhan Ekonomi dan Tabungan Domestik". Prisma, No.9, Jakarta.

Musgrave, R.A and P.B Musgrave. (1976). Public Finance in Theory and Practise, Mc Graw Hill, New York.

Ofik Taufik Robiyana. (2003). Analisis Pengaruh PDRB dan Laju Pertumbuhan Ekonomi Terhadap Pendapatan Asli Daerah Dati II di Jawa Barat Periode 1994-2001, Skripsi UNPAD.

Robock and Simonds. (1989). International Business \& Multinational Enterprises, Fourth Edition, Richard D. Irwin, inc, Homewood, Illinois.

R. Santoso Brotodiharjo. (1998). Pengantar Ilmu Hukum Pajak, PT Refika Aditama, Bandung.

Sadono Sukirno. (1981). Teori Ekonomi Makro, LPFEUI, Jakarta.
Statistik Ekonomi dan Keuangan Indonesia (SEKI) Bank Indonesia

Thee Kian Wie, 1975, Penanaman modal Asing dan Pengembangan Negaranegara Berkembang, Prisma, No 6 Desember.

Todaro, P. Michael, 1998, Pembangunan Ekonomi di Dunia Ketiga, Edisi Keenam, Erlangga, Jakarta. 